\title{
Fine structures of rare earth element patterns of Tahitian rocks
}

\author{
YASUTAKA TERAKADO \\ Institute of Geosciences, College of Liberal Arts, \\ Kobe University, Nada, Kobe 657 Japan
}

(Received June 6, 1980; Accepted November 19, 1980)

\begin{abstract}
Rare earth element (REE) contents of alkaline rocks from Tahiti have been determined. Their chondrite normalized patterns are characterized by relative enrichment of the light REE, as is common in other alkaline rocks. Additionally, two distinct fine structures are seen, especially in basic rocks: An upward-concave shape of the heavy REE span and an inflection in the light REE span. The author has attempted to explain these fine structures and to derive information on the petrogenetic processes based on calculated models. It is concluded that the upward-concave shape is generated under high pressure conditions corresponding to the deeper part of the uppermost mantle. Furthermore, considerably large amounts of clinopyroxene fractionation are needed to explain both the inflectional feature of the light REE span and the upward-concave shape of the heavy REE span. The most appropriate model for the parental magma for Tahitian rocks is 6 to $10 \%$ melting of a garnet peridotite mantle followed later by 60 to $70 \%$ of clinopyroxene fractionation at high pressure.
\end{abstract}

\section{INTRODUCTION}

Oceanic islands formed by volcanism in oceanic basins independent of plate boundaries deserve attention because they are a key to a better understanding of the mantle and physical or chemical processes occurring under oceanic lithosphere. WiLson (1963) and Morgan (1972) have suggested that the rectilinear island chains in the Pacific Ocean are created by sequential volcanism which is due to the motion of the Pacific plate over a "hot spot" in the mantle below the drifting lithosphere. It is interesting that subparallel island line segments can be seen in the area of south-central Pacific Ocean near Tahiti. Strontium isotopic studies and potassium-argon age determinations have been made for this area (DUNCAN and COMPSTON, 1976; DunCan and MCDougall, 1976; Hedge, 1978). In the present paper, the author would like to report rare earth element (REE) data on Tahitian rocks and discuss the genesis of magma in the oceanic mantle from which several kinds of rocks are produced.

The rocks of Tahiti can be considered typical of strongly alkaline rocks occurring in the Pacific Ocean. Their chemical and pterographycal data have been reported by McBIRNEY and AOKI (1968) who provided the samples used in this study.

Many workers have recognized that the abundances of rare earth elements in alkali-rich rocks can be explained by a lower proportion of partial melting of a peridotite mantle (e.g., SCHILling and WincheSTER, 1969; GAST, 1968; KAY and GAST, 1973; SUN and HANSON, 1975; Shimizu and Arculus, 1975). KAY and Gast (1973) measured rare earth element contents of alkali-rich silica-undersaturated basalts erupted onto oceanic and continental plates, and examined the possible conditions for partial melting of garnet peridotite mantle. In their model calculations, the partition coefficients for several of the constituent minerals of peridotite were assumed and the garnet-clinopyroxene ratio, percentage of melting and total REE content of a peridotite mantle were varied. They concluded, for example, that nephelinite is produced by $1 \%$ melting of peridotite with a clinopyroxene-garnet ratio of $1: 1$. It should be 
noted that the calculated REE pattern is strongly affected by partition coefficients assumed for the minerals, in both the REE pattern and absolute level. It is well known that partition coefficients vary with temperature, pressure and chemical composition of the phases. Recently, our knowledge of REE partition coefficients for various rock forming minerals has grown and become more precise with advancing studies of the factors controlling the trace element partitioning between silicate minerals and melts in both natural and synthetic systems. In this study, the author examines the partition coefficients with special attention to a clinopyroxene-basaltic melt and garnet-basaltic melt in order to calculate hypothetical REE patterns.

Despite the importance of rare earth elements in petrogenetic studies, the fine structures in the shape of chondrite-normalized REE patterns, aside from Eu anomaly, are seldome discussed. For this reason, I have attempted to extract useful information on the constraints for the possible genetic models from the fine structures of the REE patterns. For the purpose of these inquiries, it is necessary to measure the REE contents of the samples very accurately (to at least less than 2 to $3 \%$ ). Furthermore, the relative relationship of each point constituting the REE pattern should receive more consideration than the absolute level of the pattern, because the REE patterns for the rocks which occur in a certain suites tend to have common features in their patterns, even if the absolute levels of the patterns in the diagram have a large range.

\section{Samples and Analytical Technique}

Powdered samples of Tahitian rocks used in this study were provided by A. R. MCBIRNEY. The major element compositions (Table 1) and petrographic data of the samples have been precisely determined by MCBIRNEY and AOKI (1968), and it has been shown that the differentiated rocks diverged or split into two distinct trends that include both effusive and plutonic rocks. The end members of one of these series are trachytes and syenites that are nearly saturated with silica, the other series ends with strongly undersaturated phonolites and nepheline syenites. Despite the significant differences between effusive and plutonic rocks in their mineralogical aspects, there appears to be no remarkable discrepancies between effusive and plutonic rock series with respect to major element compositions. The island of Tahiti consists of two adjacent volcanoes, Tahiti-nui on the west and Taiarapu on the east, but it is difficult to distinguish petrochemical differences between the volcanoes by using major elements and petrographical data. Furthermore, it was noted that one of the samples (I-52, an olivineaugite basalt) was the most primitive magma of both of the Tahitian rock series (MCBIRNEY and AOKI, 1968).

The REE contents have been determined by the method of isotopic dilution. The chemical procedures for REE analyses employed in this study are similar to those of MASUdA (MASUDA, 1966; MASUDA et al., 1973). The accuracies of the usual determination are believed to be about $1 \%$, but in some cases, especially in the heavy REE, errors of 2 to $3 \%$ may occur.

\section{RESUlts}

Results of the REE analyses are given in Table 2. The whole rock abundances normalized to Leedey (MASUd et al., 1973) (Fig. 1) show a moderate enrichment of the light REE common to all rock types. However, the extremely large fractionation of the light REE, such as the potassic basalts reported by KAY and GAST (1973), is not seen in this case. It is interesting that there are several patterns showing small enrichment of the light REE compared with other alkaline rocks: for example, chondritenormalized value of $\mathrm{La}$ for $\mathrm{I}-37$ is only 34.5. Moreover, most REE patterns in Tahitian rocks, aside from I-45, are roughly parallel with one another. These parallel relationships among the differentiated rocks have been observed in intrusive bodies (e.g., HASKIN and HASKIN, 1968; TANAKA, 1974) and oceanic floor basalts (KAY 
Table 1. Chemical compositions of Tahitian rocks

\begin{tabular}{|c|c|c|c|c|c|c|c|c|c|c|c|}
\hline \multicolumn{4}{|c|}{ Basic End-members } & \multicolumn{4}{|c|}{ Main Series } & \multicolumn{4}{|c|}{ Nephelinic Series } \\
\hline & & & & \multicolumn{2}{|c|}{ Plutonic } & \multicolumn{2}{|c|}{ Effusive } & \multirow{2}{*}{$\begin{array}{c}\text { Pluto. } \\
\text { I-62 }\end{array}$} & \multicolumn{3}{|c|}{ Effusive } \\
\hline & I-52 & $\mathrm{I}-48$ & I-60 & I-37 & I-58 & $1-70$ & $\mathrm{I}-69$ & & I-67 & I-53 & I-45 \\
\hline $\mathrm{SiO}_{2}$ & 45.53 & 43.82 & 37.25 & 41.75 & 46.35 & 48.89 & 61.18 & 45.30 & 42.35 & 48.50 & 55.81 \\
\hline $\mathrm{TiO}_{2}$ & 3.18 & 3.00 & 5.75 & 4.27 & 4.42 & 2.46 & 0.76 & 3.57 & 4.78 & 2.68 & 0.26 \\
\hline $\mathrm{Al}_{2} \mathrm{O}_{3}$ & 12.83 & 10.80 & 9.64 & 17.35 & 16.97 & 16.92 & 19.16 & 16.97 & 16.61 & 17.53 & 22.00 \\
\hline $\mathrm{Fe}_{2} \mathrm{O}_{3}$ & 3.92 & 4.67 & 8.86 & 5.71 & 2.22 & 3.44 & 1.70 & 2.61 & 3.80 & 4.43 & 1.68 \\
\hline $\mathrm{FeO}$ & 8.93 & 8.30 & 8.35 & 7.40 & 8.80 & 6.47 & 1.50 & 4.49 & 7.84 & 3.73 & 0.89 \\
\hline $\mathrm{MnO}$ & 0.16 & 0.17 & 0.18 & 0.14 & 0.08 & 0.13 & 0.12 & 0.06 & 0.13 & 0.12 & 0.06 \\
\hline $\mathrm{MgO}$ & 8.90 & 11.89 & 9.26 & 7.39 & 3.72 & 3.30 & 0.78 & 5.61 & 5.56 & 4.32 & 0.21 \\
\hline $\mathrm{CaO}$ & 12.38 & 12.03 & 15.61 & 11.67 & 8.38 & 5.85 & 1.58 & 7.86 & 10.03 & 6.21 & 0.93 \\
\hline $\mathrm{Na}_{2} \mathrm{O}$ & 2.30 & 2.03 & 1.67 & 2.17 & 4.14 & 4.76 & 6.36 & 4.61 & 3.85 & 6.79 & 9.26 \\
\hline $\mathrm{K}_{2} \mathrm{O}$ & 1.05 & 0.70 & 0.97 & 0.69 & 2.27 & 4.28 & 5.17 & 4.27 & 1.96 & 3.54 & 5.45 \\
\hline $\mathrm{H}_{2} \mathrm{O}^{+}$ & 0.71 & 1.58 & 1.52 & 1.22 & 1.41 & 0.49 & 0.83 & 2.47 & 1.27 & 0.91 & 2.17 \\
\hline $\mathrm{H}_{2} \mathrm{O}^{-}$ & 0.34 & 0.42 & 0.04 & 0.17 & 0.13 & 0.06 & 0.61 & 0.29 & 0.45 & 0.47 & 0.46 \\
\hline $\mathrm{P}_{2} \mathrm{O}_{5}$ & 0.32 & 0.35 & 0.89 & 0.14 & 0.91 & 1.91 & 0.13 & 1.42 & 0.90 & 0.62 & 0.02 \\
\hline & 100.55 & 99.76 & 99.99 & 100.07 & 99.80 & 99.23 & 99.88 & 99.53 & 99.71 & 99.85 & 99.20 \\
\hline
\end{tabular}

Major element compositions are from MCBIRNEY and AOKI (1968).

Key to Table 1 (Microscopical observations by MCBIRNEY and AOKI, 1968).
I-52: Olivine augite basalt
1-69: Trachyte
I-48: Olivine teralite
I-60: Yamaskite
1-62: Nepheline monzonite
I-37: Theralite
I-67: Basanite
I-58: Essexite
1-53: Tahitite
I-45: Phonolite

I-70: Aphyric tahitite

Table 2. REE abundances (ppm) in Tahitian rocks

\begin{tabular}{cccccccccccc}
\hline \hline Sample & I-52 & I-48 & I-60 & I-37 & I-50 & I-70 & I-69 & I-62 & I-67 & I-53 & I-45 \\
\hline La & 26.5 & 27.6 & 36.2 & 13.2 & 55.0 & 120.6 & 102.3 & 66.9 & 54.3 & 98.7 & 71.7 \\
Ce & 61.0 & 58.6 & 92.8 & 30.8 & 121.5 & 273.0 & 213.6 & 141.4 & 131.4 & 223.3 & 83.6 \\
Nd & 35.3 & 33.9 & 61.5 & 18.6 & 61.1 & 116.9 & 87.5 & 74.7 & 80.2 & 84.8 & 11.1 \\
Sm & 7.84 & 7.69 & 14.1 & 4.29 & 12.5 & 22.4 & 15.6 & 17.7 & 16.4 & 15.3 & 1.18 \\
Eu & 2.44 & 2.31 & 4.20 & 1.57 & 3.87 & 6.02 & 4.15 & 5.05 & 5.13 & 5.00 & 0.323 \\
Gd & 7.31 & 6.70 & 12.2 & 4.01 & 10.4 & 15.5 & 10.8 & 13.8 & 14.7 & 12.1 & 0.993 \\
Dy & 5.84 & 5.17 & 8.02 & 3.07 & 7.47 & 10.9 & 9.11 & 9.10 & 9.93 & 9.17 & 1.39 \\
Er & 2.68 & 2.17 & 2.78 & 1.31 & 3.02 & 4.39 & 4.42 & 3.17 & 3.83 & 4.58 & 1.33 \\
Yb & 2.10 & 1.61 & 1.69 & 0.986 & 2.20 & 3.44 & 3.64 & 2.02 & - & 3.70 & 2.02 \\
Lu & 0.312 & 0.233 & 0.231 & 0.140 & 0.302 & 0.472 & 0.544 & 0.258 & 0.350 & 0.502 & 0.361 \\
\hline
\end{tabular}

et al., 1970) and are suggestive of shallow magmatic differentiation. In contrast, the REE patterns in some alkaline rock suite do not show parallel enrichment but exibit larger variation in the light REE than in the heavy REE: if the light REE pattern is assumed to be close to a straight line, the inclinations of such patterns in a certain suite vary with their rock types or major element compositions (ScHILLING and WinCHester, 1969; Shimizu and ARCUlus, 1975).

A small positive Eu anomaly can be seen in only two samples, I-37 and I-53, though faint
$\mathrm{Eu}$ anomalies have been reported for other alkaline rock suites (KAY and GAST, 1973; Shimizu and ARCulus, 1975; NAGASAWA, 1973; SUN and HANSON, 1975). The absence of a Eu anomaly, except for I-37 and I-53, seems to be in harmoney with the petrographic observations that almost all mafic lavas are characterized by the absence of feldspar phenocrysts. MCBIRNEY and AOKI (1968) suggested that anorthoclase is common in differentiated lavas and is probably a late crystallizing mineral of many theralites. I-37 and I-53 are classified into theralites. It 
seems appropriate to consider, therefore, the possibility that relative enrichment of $\mathrm{Eu}$ was caused by the concentration of anorthoclase having a large positive Eu anomaly (NAGASAWA, 1973) relative to the essential theralite magma. Neverthless, it is important to note that plutonic rocks containing plagioclase or alkali feldspar do not show $\mathrm{Eu}$ anomaly.

As seen in Fig. 1, the overall pattern for I45 (phonolite) is upward concave, depleted in the middle REE and enriched in the heavy REE. Almost the same patterns as for I-45 were reported by Simmons and Hedge (1978) and it is noteworthy that those rocks, like I-45, are commonly characterized by high alkali contents and have strongly differentiated major element compositions. It appears that development of upward-concave patterns requires fractionation of a phase with high partition coefficients for middle REE. In general, the partition coefficients for REE increase with increasing silica content of magma (RYERSON and HESS, 1978), even though the general shapes of the pattern are preserved. In fact, the high values of the partition coefficients for clinopyroxene-rich intermediate rocks and hornblende-rich intermediate rocks

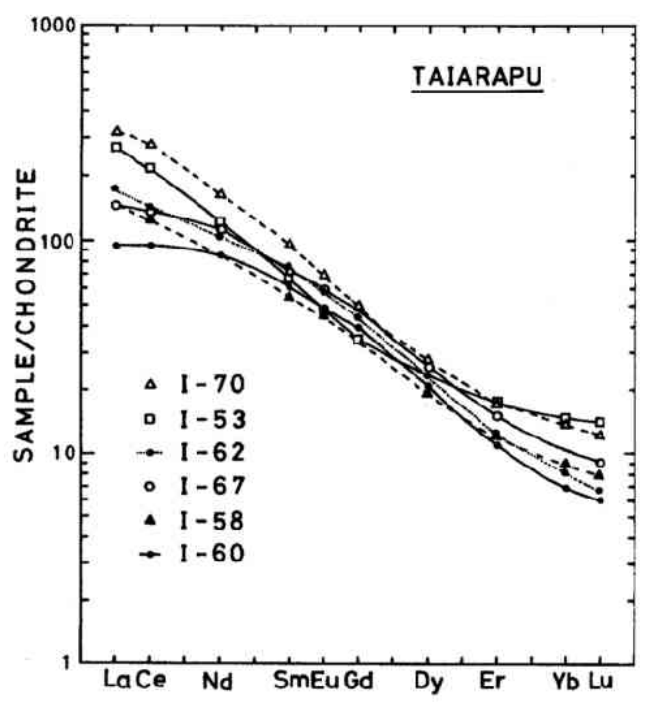

Fig. 1a were reported by SchNETZLer and Philpotts (1970) and Nagasawa and SCHNETZler (1971), respectively. In the case of $\mathrm{I}-45$, it is appropriate to consider that the parental magma underwent crystallization of clinopyroxene or hornblende which had high partition coefficients for the middle REE. Accessory minerals such as zircon or apatite that concentrate the REE (NAGASAWA, 1970) may also have participated in the magmatic differentiation processes. However, the major-element composition of I-45 suggests separation of mafic minerals from the magma, since $\mathrm{CaO}, \mathrm{MgO}$ and total iron are extremely low in I-45.

\section{Fine Structures of the REE Pattern}

In addition to the large-scale REE patterns pointed out in the preceeding section, there are also small-scale features which can be seen in the shape of their patterns. In order to show the fine structure of the pattern more clearly on the diagram (Fig. 2), the Nd-Gd joins are drawn with extentions. The following two points are noted: (1) The heavy REE span is upward-concave. (2) In the light REE span,

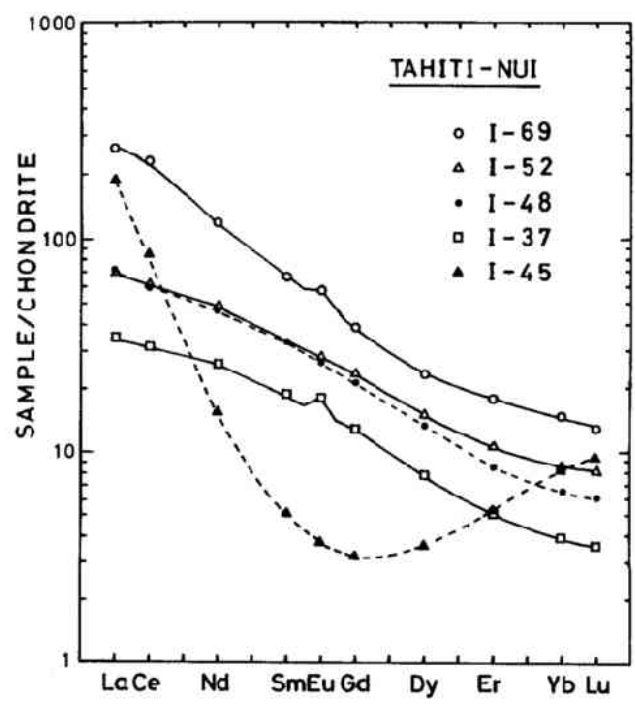

Fig. 1b

Fig. 1a. Chondrite-normalized REE patterns for alkaline rocks from Taiarapu volcano of Tahiti.

Fig. 1b. Chondrite-normalized REE patterns for alkaline rocks from Tahiti-nui volcano of Tahiti. 
there is a slight inflection at $\mathrm{Nd}$.

The upward-concave shape is clearly seen in the case of Hawaiian nephelinite (Fig. 3-A) (KAY and GAST, 1973), though the light REE show good linearlity. On the other hand, the inflected light REE pattern of an ankaramite from the Lesser Antilles was reported by HAWKESWORTH et al. (1979) (Fig. 3-B). It is noteworthy that despite a limited number of data showing fine structures, the samples which have the same characteristics seem to be broadly akin to each other in that they are from similar alkaline suites (Qualified data are limited because few are precise enough to demonstrate the fine structures examined here). To my knowledge, these fine structures of the REE pattern have never been discussed before. In the present paper, I would like to consider what information can be extracted from the fine structures and how useful such information can be.

Several possibilities could be considered for the interpretation of the fine structures of the pattern. Alteration or weathering may be a possibility, but this seems not to be important, because the samples that exhibit the fine structures on the REE pattern appear to be fresh. Furthermore, the behavior of rare earth elements

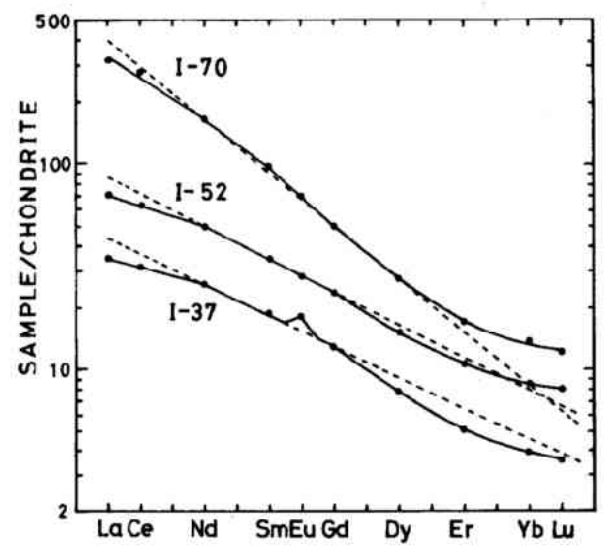

Fig. 2. Chondrite normalized REE patterns for selected samples, aphyric tahitite (I-70), olivine augite basalt (I52) and theralite (1-37). Broken lines that tie $N d$ and $G d$ are drawn to show the fine structures clearly. Note the inflectional features in the light REE span and the upward-concave curves in the heavy REE span. in weathering of sea floor basalts studied by LUDDEN and THOMPSON (1979) show a strong mobility of the light REE, but the effect differs from the fine structures observed in this study.

Another possibility is that the ascending magma was contaminated by the oceanic lithosphere. This is also precluded by data for the oceanic floor basalts or sediments which do not show the pronounced fine structures mentioned in this study.

Moreover, it can be considered that the fine structures of the Tahitian rocks reflect the original pattern of the source materials in the mantle. According to such a line of thought (source effect), the effect in question may be examined in two ways. First, the source rocks might maintain the REE abundances inherited from the primitive earth, and an original mantle

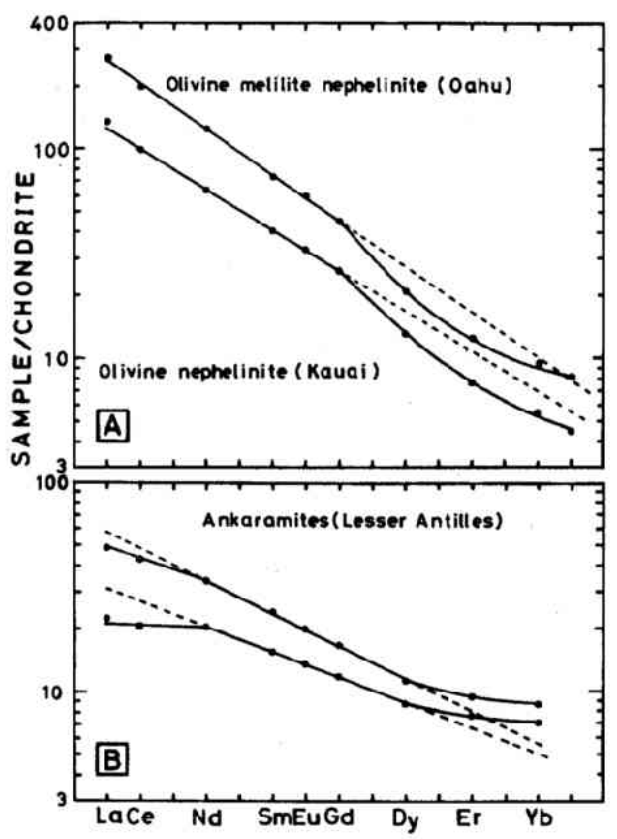

Fig. 3. Chondrite-normalized REE patterns for selected nephelinites from Hawaii $(A)$ and ankaramites from Lesser Antilles (B). Upward-concave shapes can be recognized in $(A)$, though the light REE spans show almost straight line. Ankaramites $(B)$ indicates inflectional shapes in the light REE span. Data on $A$ and $B$ are from KAY and GAST (1973) and HAWKESWORTH et al. (1979), respectively. 
source produced by chondritic meteorite might already have had the observed fine structures. However, it seems difficult to adopt this possibility, because the REE patterns of chondritic meteorites (MASUDA et al., 1973; EVENSEN et al., 1978) do not show the same fine structures as markedly observed in Tahitian rocks. Another alternative is that source materials were affected during differentiation of the mantle before the production of the parental magma of the Tahitian rocks. In fact, DUNCAN and COMPSTON (1976) and HEDGE (1978) have pointed out that the sub-Pacific mantle was originally homogeneous but that incipient differentiation with respect to the $\mathrm{Rb}-\mathrm{Sr}$ system had taken place one billion years or more ago. This fact implies a mantle heterogeneity which has recently been supported by $\mathrm{Nd}$ isotope data for various areas (e.g., Zindler et al., 1979). But it would be difficult to discuss the fine structures in terms of Nd isotopes. Furthermore, it should be noted that the fine structures must be explained even in the case of previous or incipient differentiation processes of mantle in Precamblian time.

Apparently, the most significant and realistic explanation is that the fine structures are created during petrogenetic processes such as partial melting or crystal fractionation, in which the rare earth elements are distributed between solid and liquid phases. In other words, the partitioning of REE among solids and liquid prior to the separation of phases gives rise to the specific shape in their REE patterns. Hence, this effect depends on the models employed and on the shape of the partition coefficient pattern for each mineral involved in the process.

\section{Model Calculations}

First, I would like to examine the upwardconcave shape on the heavy REE span on the basis of models for partial melting and crystal fractionation. Nowadays, the alkaline rocks are considered to be formed by small degrees of partial melting at relatively deep levels of the uppermost mantle. In this section, however, not only partial melting but also fractional crystallization will be considered, because most of the Tahitian rocks have been shown to be derived from differentiated magmas which have undergone crystal fractionation of their major elements by MCBIRNEY and AOKI (1968).

The mathematical treatment of trace element fractionation during partial melting has been derived and discussed by many workers (e.g., GAST, 1968; Hertogen and GiJBELS, 1976; LUNGMUIR et al., 1977). In this paper, I have chosen mainly the model for batch partial melting represented by equation (15) in SHAW (1970).

The well-known Rayleigh law is also used for fractional crystallization model (cf. MASUDA and MATSUi, 1966; Allegre et al., 1977). If two or more phases are crystallizing, the bulk partition coefficient $\overline{\mathrm{D}}$ can be represented by a weighted mean of partition coefficients of phases concerned. Namely, this coefficient is defined by $\bar{D}=\Sigma D_{i} \cdot X_{i}$, where $X_{i}$ is the fractional contribution of phase $i$, and $D_{i}$ is the solid/liquid partition coefficient for phase $i$.

Partition coefficient Throughout this paper, the partition coefficient is defined as a ratio of the concentration of an element in the solid to

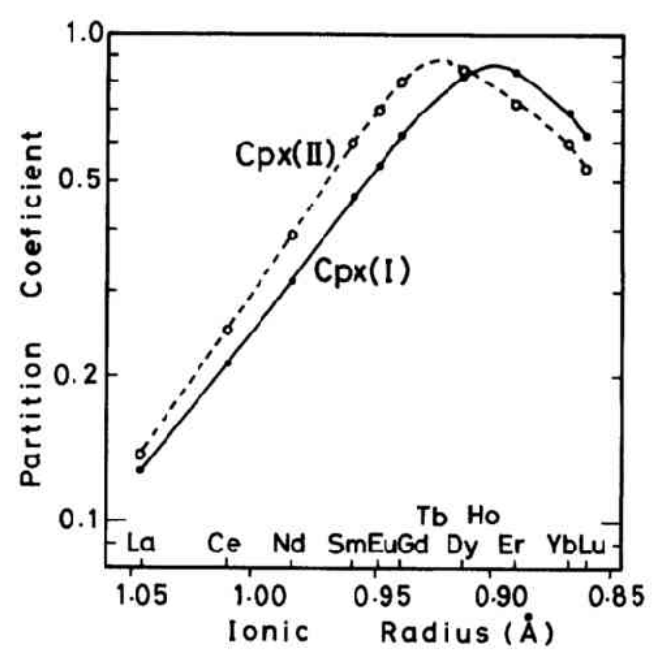

Fig. 4. Comparison of two sets of REE partition coefficient functions for clinopyroxene. Partition coefficients are listed in Table 3 and plotted against ionic radius (SHANNON and PREWIIT, 1970). 
Table 3. Assumed partition coefficients of REE between silicates and silicate melts

\begin{tabular}{llcccc}
\hline \hline & Garnet & Cpx (I) & Cpx (II) & Olivine & Opx. \\
\hline La & 0.0007 & 0.127 & 0.137 & 0.0020 & 0.0010 \\
$\mathrm{Ce}$ & 0.0054 & 0.212 & 0.250 & 0.0028 & 0.0023 \\
$\mathrm{Nd}$ & 0.033 & 0.312 & 0.390 & 0.0037 & 0.0051 \\
$\mathrm{Sm}$ & 0.102 & 0.463 & 0.598 & 0.0045 & 0.0087 \\
$\mathrm{Eu}$ & 0.183 & 0.537 & 0.698 & 0.0049 & 0.013 \\
$\mathrm{Gd}$ & 0.330 & 0.620 & 0.799 & 0.0055 & 0.020 \\
$\mathrm{Dy}$ & 1.08 & 0.816 & 0.838 & 0.0067 & 0.026 \\
$\mathrm{Er}$ & 2.80 & 0.830 & 0.715 & 0.0082 & 0.044 \\
$\mathrm{Yb}$ & 5.40 & 0.690 & 0.592 & 0.0100 & 0.076 \\
$\mathrm{Lu}$ & 6.50 & 0.620 & 0.530 & 0.0120 & 0.100 \\
\hline
\end{tabular}

that in the liquid. The partition coefficients listed in Table 3 (Fig. 4) are obtained in light of the concept that on a partition coefficient diagram with a lagarithmic ordinate and ionic radius as abscissa, data points fall on a smooth curve and indicate peaks corresponding to their crystallographic sites. Data examined to presume these partition coefficients are selected from phenocryst/groundmass or megacryst/host rock partition coefficients (SCHNETZLER and PhilPOTTS, 1968; ONUMA et al., 1968; SCHNETZLER and Philpotts, 1970) and experimental investigations (MASUdA and KUSHIRO, 1970; SHIMIZU and KUSHIRO, 1975; MASUdA et al., 1977). It would be expected that small variations in the partition coefficients for olivine and orthopyroxene do not cause a significant change in the calculated REE pattern, because their partition coefficient values are very small compared with unity. On the other hand, garnet and clinopyroxene have partition coefficients large enough to have a pronounced effect on the resultant pattern. Garnet/basic magma partition coefficients used in this study are based on those of IRVING and FREY (1978) in which the pyrope/ host partition coefficients are fairly uniform and agree with experimental data within a factor of 2. Schnetzler and Philpotts (1970) have indicated that relative values of the partition coefficients for Ca-clinopyroxene are quite similar, although there is at least a range of an order of magnitude in the absolute values, and have recognized that the clinopyroxene reported by ONUMA et al. (1968) has a pattern that is essentially indistinguishable from a normal clino- pyroxene pattern. The REE partition coefficients for clinopyroxene demosntrate a peak on the partition coefficient-ionic radius diagram corresponding to the M2 site in the clinopyroxene crystal structure. Various kinds of partition coefficients have been observed for clinopyroxene in which the peak has various positions within the heavy REE span. Two sets of partition coefficients for clinopyroxene are used in this study: One has a peak on Ho and the other on $\mathrm{Tb}$ (Fig. 4).

Results of model calculations Four examples of the calculations using a four-phase mantle source (garnet $10 \%$, clinopyroxene $10 \%$, orthopyroxene $20 \%$, olivine $60 \%$ ) and a melting contribution of each phase to the liquid (garnet $40 \%$, clinopyroxene $40 \%$, orthopyroxene $10 \%$, olivine 10\%) are shown in Fig. 5: for partition coefficients employed, see Table 3. Three cases of different degrees of melting, 0.5, 4 and $12 \%$, are indicated by (A), (B) and (C), respectively. An upward-concave shape roughly comparable with the observed one can be seen in (A) of Fig. 5. In the case (B), the curvature of the upward-concave shape becomes much less pronounced, while in the case of (C), the shape becomes almost rectilinear. According to these model calculations, it seems appropriate to conclude that a small degree of melting (less than about 1 to $2 \%$ ) is needed to give a heavy REE pattern with an upward-concave shape. The hypothetical chondrite-normalized REE pattern generated by using the relative enrichment factor of (A) in Fig. 5 and assuming about 5 
times chondritic abundances for REE contents of original source is remarkably in harmony with that of Hawaiian nephelinite (Fig. 3-A). Moreover, it is interesting to find a good concurrence of a slight $\mathrm{La}$ and $\mathrm{Ce}$ deviation from the light REE line between the calculated pattern (Fig. 5A) and observed nephelinites (Fig. 3-A).

It can be easily understood that the upwardconcave shape reflects substantially the shape of the REE partition coefficient function for garnet and that for clinopyroxene. In particular, the peak location of the clinopyroxene partition coefficient function is the most important factor responsible for the fine structure of the heavy REE span. As illustrated in Fig. 4, the two types of partition coefficient function for clinopyroxene, Cpx (I) Cpx (II) (cf. Table 3), used in this study have different peak positions in the heavy REE span. Cpx (I) has a peak, which corresponds to the M2 site for clinopyroxene crystal structure, in the vicinity of Ho and has been used for the calculations of (A), (B) and (C) of Fig. 5. On the other hand, (D) of Fig. 5 is calculated by using $\mathrm{Cpx}$ (II) instead of $\mathrm{Cpx}$ (I) of (A); Cpx (II) has a peak position at $\mathrm{Tb}$ rather than Ho. The change of the peak location in the REE partition coefficient functions for clinopyroxene causes a significant change in the shape of the heavy REE span. In comparison of (A) with (D) of Fig. 5, dy of (A) forms the upwardconcave curve together with other heavy REE, though Dy of (D) falls on an almost straight line together with the light REE.

The same effect of the peak location of clinopyroxene partition coefficient functions can clearly be noted in the case of the model for fractional crystallization. Six examples for cocrystallization of garnet and clinopyroxene are shown in Fig. 6. A good upward-concave shape can be seen in (A); parameters for the calculation are $0.085 / 0.915$ and 0.1 for garnet/clinopyroxene proportion and for residual liquid fraction, respectively. To show the effect of the garnet/clinopyroxene ratio on the heavy REE pattern, the calculated patterns (B) and (C) are indicated for the different proportions, 0.05/ $0.950 .12 / 0.88$, respectively, with the same

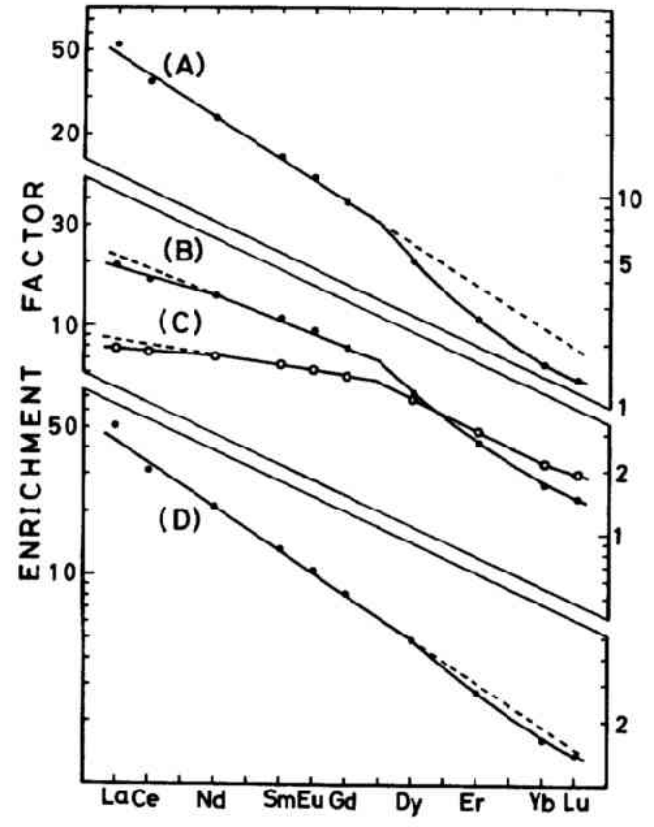

Fig. 5. Enrichment factor of REE in melts produced by partially melting garnet peridotites (Gr 10\%, Cpx 10\%, Opx 20\%, and Ol 60\%). Phase contributions to the liquids are Gr 0.4, Cpx 0.4, Opx 0.1, and 010.1 in common to $A, B, C$ and $D$. Melting proportions are $0.005,0.04$ and 0.12 for $A, B$ and $C$, respectively; the corresponding values for $D$ is 0.005 . The partition coefficients used in these calculations are given in Table 3. Cpx (I) is adopted for $A, B$ and $C$, but $C p x$ (II) is used for $D$ (see explanations in text).

residual liquid fraction 0.1 . When (A), (B) and (C) are compared, it can be understood that the larger contribution of clinopyroxene to the bulk solid phase (i.e., (B)) gives rise to a greater sagging in the heavy REE span. (D) and (E) of Fig. 6 are illustrated to show the effect of the peak location of Cpx (II)-type partition coefficient functions. In those patterns showing a slightly convex-upward shape in their heavy REE span represented by $\mathrm{Dy}, \mathrm{Er}, \mathrm{Yb}$ and $\mathrm{Lu}$, as for (D), the same parameters as applied to (A) were employed, while somewhat different ones were used for (E). As discussed in the preceeding case of partial melting, it is also difficult in this model to elucidate the upward-concave shape by using the clinopyroxene/liquid parti- 


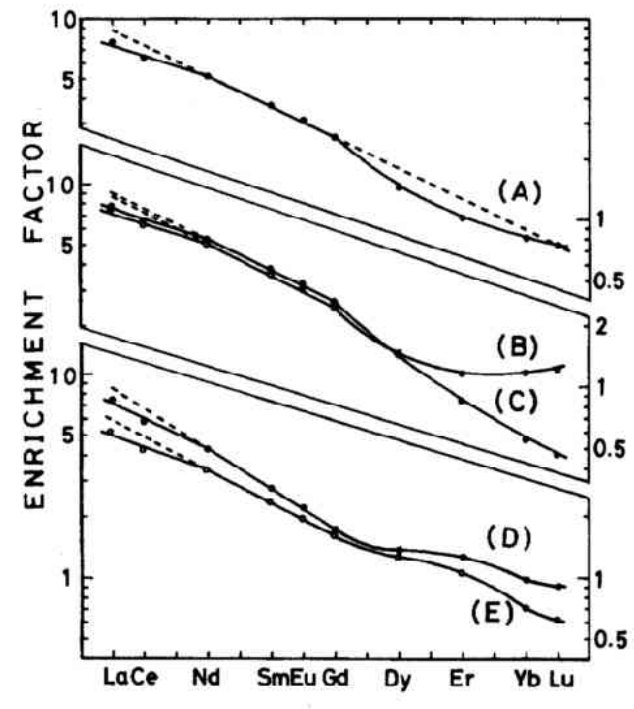

Fig. 6. Enrichment factors of REE in residual melts during fractional crystallization processes. Throughout these examples, both garnet and clinopyroxene are crystallized and their proportions with assumed residual liquid fractions shown parenthetically are 0.085/0.915 (0.1), $0.05 / 0.95$ (0.1), $0.12 / 0.88$ (0.1), $0.085 / 0.915$ (0.1) and $0.12 / 0.88(0.15)$ for $A$ to $E$ in this sequence. The partition coefficients used for these calculations are given in Table 3. Cpx (I) is used for A, B and C, but $C p x$ (II) for $D$. and $E$.

tion coefficient function with a peak near $\mathrm{Tb}$ (Cpx-II). Regardless of the models chosen for the calculations, it is worth noting that the fine structure of REE pattern, especially in the heavy REE span, depends strongly on the peak location of clinopyroxene partition coefficient function. Conversely speaking, we can get information about the peak location of the partition coefficient function for a clinopyroxene that has participated in the magmatic processes.

Furthermore, it should be noted that there is an abrupt increase of garnet partition coefficients between the light REE and the heavy REE: The partition coefficients for the light REE (La to Gd) are less than unity but those for the heavy REE are greater than unity. This remarkable change on the partition coefficient function for garnet is a factor for the salient differences between the inclination of the light
REE span and that of the heavy REE span (cf. (C) of Fig. 5, and (C) of Fig. 6).

According to these calculations, an important point is that the upward-concave shape is created by using both garnet and Cpx(I)-type clinopyroxene. The necessity of both clinopyroxene and garnet for the explanation of upward-concave shape suggests that the clinopyroxenes must be formed at a high pressure at which garnet is stable. Hence, Cpx(I) type clinopyroxene may be formed under high pressure. On the other hand, Cpx(II)-type clinopyroxene also crystallizes in the magmatic process of Tahitian rocks, because Cpx(II)-type partition coefficient with a peak near $\mathrm{Tb}$, was observed in an augite from a Tahitian ankaramite by Schnetzler and Philpotts (1968). This suggests shallow fractionation, possibly in a magma chamber just under the oceanic crust. However, shallow fractionation is not the dominant process in forming basic Tahitian rocks, such as I-52 (Fig. 2), which is considered the parental magma of Tahitian rock series (MCBIRNEY and AOKI, 1968). In light of the discussions above, it seems reasonable to consider that the peak position for clinopyroxene partition coefficient function shifts to smaller ionic radius with increasing pressure. According to this speculation, the partition coefficient function having a peak in smaller ionic radius like $\mathrm{Cpx}$ (I)-type would be an effective way to treat phenomenon occurring at high pressures.

There seems to be some evidence supporting this hypothesis, though experimental data on the effect on the peak position for clinopyroxene partition coefficient functions are scarce. The REE partition coefficient, for example, between augite megacrysts and an alkali lava reported by ONUMA et al. (1968) exhibits almost the same pattern as Cpx(I) especially in their peak position. The same augite megacrysts were previously studied by KuNo (1965) and concluded to be formed under high pressure condition because of its high $\mathrm{Al}$ content. Recently, Nicholls and HARRIS (1980) have reported experimental results on REE partitioning between clinopyroxene and liquid 
under different pressure conditions; the REE partition coefficient pattern for $15 \mathrm{~Kb}$ experiment has a peak near Gd. On the other hand, the pattern for $35 \mathrm{~Kb}$ shows a peak near Ho.

\section{Inflectional feature in the light REE span}

As

seen in Figs. 5 and 6, the pattern with an inflectional point near $\mathrm{Nd}$ is developed by both partial melting and fractional crystallization model. As to the partial melting model, (A) of Fig. 5, which corresponds to $0.5 \%$ melting, does not show this fine feature but (B) and (C) of Fig. 5 show a deviation of $\mathrm{La}$ and $\mathrm{Ce}$ downward from the light REE extention shown by a broken line. In the case of partial melting, a lower degree of melting (less than $2 \%$ ) gives an almost straight line for light REE span and an upward-concave shape in heavy REE span, but a greater degree of melting (more than 3\%) displays an inflectional feature in the light REE span, though the upward-concave shape cannot be seen in the heavy REE span. Hence, it can be concluded that in the process of partial melting, the inflectional structure would not be compatible with the upward-concave shape.

On the other hand, the inflectional feature is always observed in the fractional crystallization model and can be compatible with upwardconcave shape. Accordingly, the fractional crystallization model seems to be preferable to the partial melting one. However, it would also be possible to explain the relations in terms of a combination of fractional crystallization and partial melting. Namely, the two step-model in which clinopyroxene fractionation has taken place subsequent to a large degree of partial melting appears to elucidate those fine structures. In this case, clinopyroxene with maximum partition coefficients near Ho contributes an upward-concave shape in the heavy REE. For example, the observed fine structures of $\mathrm{I}-52$ indicating both inflectional and upward-concave shapes are accounted for satisfactorily by assuming fifty to seventy percent of crystal fractionation combined with six to ten percent of preceding partial melting

Some workers may suspect that a large degree of clinopyroxene fractionation would change the major-element composition of residual liquid significantly and that its composition would become far from the realistic chemical compositions for rocks. However, if a high pressure-type clinopyroxene characterized by high aluminum content are removed from the basaltic system, it is conceivable that the compositions of the liquid would not change much with crystal fractionation relative to the initial compositions of the system. Actually, some experimental results for high-Al clinopyroxene have been reported by several workers (e.g., GreEN and Ringwood, 1967; NAKAMURA and MASUdA, 1976; Nicholls and HarRIS, 1980).

Minor phases (e.g., apatite, phlogopite) in which REE tend to concentrate may be included in the mantle and affect the REE concentrations of the liquid, if it is separated relatively quickly from the residual solid phase, but these minor phases will disappear into the melt during earlier stage of partial melting. Provide that a considerably large degree of melting takes place and subsequently an equilibrium between the liquid and the solid phase is attained in accord with the batch melting model, the effect of minor phases which vanish in the residual mantle source early in the melting would not come out in effect.

Moreover, relative level of REE pattern is affected by olivine fractionation in the course of the differentiation processes. However, the effect of olivine would not be large enough to change the conclusions deduced by the model calculations of the REE pattern, becuase I-52, for example, does not show extremely large $\mathrm{MgO}$ depletion which might be caused by the olivine being eliminated from the magma.

\section{CONCluding Remarks}

According to the fine structure analysis of the REE patterns for Tahitian rocks, the following two points are noteworthy:

(1) To explain the upward-concave shape in the heavy REE span, both garnet and clinopyroxene must participate in generation of the 
magma or in subsequent processes of differentiation. In addition to the participation of garnet and clinopyroxene, the partition coefficient function for clinopyroxene must have a maximum near Ho. There is some evidence which suggests that this type of clinopyroxene is stable under high pressure, while the clinopyroxene partition coefficient which has a peak near $\mathrm{Tb}$ may correspond to lower pressure. Hence, it can be concluded that the major processes for Tahitian magmas took place in relatively deep parts of the uppermost mantle. Furthermore, it would be noteworthy that the peak location of clinopyroxene partition coefficient function may vary with pressure, and we can examine the effect of the peak position by analysing the fine structures in the heavy REE pattern.

(2) To explain both the upward-concave shape of the heavy REE span and the inflectional feature of the light REE span, the fractional crystallization model is advantageous over one for partial melting. Otherwise, a two stage model, including both partial melting of garnet peridotite and clinopyroxene fractionation, becomes a possibility. In the case of partial melting, the inflectional feature can be obtained by more than $3 \%$ melting, though the upwardconcave shape can not be formed in this case. An important point is that the inflectional feature is not compatible with the upwardconcave shape in the partial melting model. It would be appropriate to conclude that the Tahitian parental magma represented by I-52 was formed by fractionation of 60 to $70 \%$ of clinopyroxene subsequent to 6 to $10 \%$ of melting of a garnet peridotite mantle.

Finally, the incipient differentiation processes deduced by $\mathrm{Rb}-\mathrm{Sr}$ study are still a problem. However, it should be emphasized that clinopyroxene plays an important role with respect to the phenomenon of magmatic processes in the mantle, and we can extract information on clinopyroxene from the fine structures of the REE pattern.

Acknowledgements-The author would like to express his cordial thanks to Professor A. R. MCBIRNEY for donating samples and making suggestions for improving the English. He is also grateful to Professor A. MASUDA for his helpful suggestions, financial support and critical reading the manuscript, and to $\mathrm{Mr}$. $\mathrm{H}$. SHIMIZU for aid in the mass spectroscopic REE analyses.

\section{REFERENCES}

ALleGre, C. J., TREUIL, M., MINSTER, J.F., MinSTER, J. B. and ALBAREDE, F. (1977) Systematic use of trace elements in igneous processes; Part I. Fractional crystallization processes in volcanic suites. Contr. Mineral. Petrol. 60, 57-75.

DUNCAN, R. A. and COMPSTON, W. (1976) Sr-isotopic evidence for an old mantle source region for French Polynesian volcanism. Geology 4, 728-732.

DunCAN, R. A. and MCDOUgall, I. (1976) Linear volcanism in French Polynesia. J. Volcanol. Geotherm. Res. 1, 197-227.

EVENSEN, N. M., HAMILTON, P. J. and O'Nions, R.K. (1978) Rare-earth abundances in chondritic meteorits. Geochim. Cosmochim. Acta 42, 1199-1212.

GAST, P. W. (1968) Trace element fractionation and the origin of tholeiitic and alkaline magma types. Geochim. Cosmochim. Acta 32, 1057-1086.

GREEN, D. H. and RINGWOOD, A. E. (1967) The genesis of basaltic magmas. Contr. Mineral. Pettol. 15, 103-190.

HASKIN, L. A. and HASKIN, M. A. (1968) Rare earth elements in the Skaergaard intrusion. Geochim. Cosmochim. Acta 32, 433-447.

HAWKESWORTH, C. J., O'NIONS, R. K. and ARCULUS, R. J. (1979) Nd and Sr isotope geochemistry of island arc volcanics, Grenada, Lesser Antilles. Earth Planet. Sci. Lett. 45, 237-248.

HEDGE, C. E. (1978) Strontium isotopes in basalts from the Pacific Ocean basin. Earth Planet. Sci. Lett. 38, 83-94.

HERTOGEN, J. and GiJBELS, R. (1976) Calculation of trace element fractionation during partial melting. Geochim. Cosmochim. Acta 40, 313-322.

IRVING, A. J. and FREY, F. A. (1978) Distribution of trace elements between garnet megacryst and host volcanic liquids of kimberlitic to rhyolitic composition. Geochim. Cosmochim. Acta 42, 771-787.

KAY, R. W., HUBbARD, N. J. and GAST, P. W. (1970) Chemical characteristics and origin of oceanic ridge volcanic rocks. J. Geophys. Res. 75, 1585-1613.

KAY, R. W. and GAST, P. W. (1973) The rare earth content and origin of alkali-rich basalts. J. Geol. 81, 653-682.

KUNO, H. (1965) Aluminian augite and bronzite in alkali olivine basalt from Taka-sima, north Kyusyu, Japan. In: Advancing Frontiers in Geology and 
Geophysics, Osumania Univ. Press, Hyderabad. 205220.

LANGMUIR, C. H., BENDER, J. F., BENCE, A. E., HANSON, G. H. and TAYLOR, S. R. (1977) Petrogenesis of basalts from the FAMOUS area: MidAtlantic ridge. Earth Planet. Sci. Lett. 36, 133-156.

LudDEN, J. N. and THOMPSON, G. (1979) An evaluation of the behavior of the rare earth elements during the weathering of sea-floor basalt. Earth Planet. Sci. Lett. 43, 85-92.

MASUDA, A. (1966) Geochemistry of lanthanides in basalts of Central Japan. Earth Planet. Sci. Lett. 4, 284-292.

MASUdA, A. and MATSUI, Y. (1966) The difference in lanthanide abundance pattern between the crust and the chondrite and its possible meaning to the genesis of crust and mantle. Geochim. Cosmochim. Acta 30, 239-250.

MASUDA, A. and KUSHIRo, I. (1970) Experimental determination of partition coefficients of ten rare earth elements and barium between clinopyroxene and liquid in the synthetic silicate system at 20 kilobar pressure. Contr. Mineral. Petrol. 26, 42-49.

Masuda, A., NAKamuRa, N. and TANAKa, T. (1973) Fine structure of mutually normalized rare-earth patterns of chondrites. Geochim. Cosmochim. Acta 37, 239-248.

MASUdA, A., Shimizu, H. and IneNaga, N. (1977) Search for chemical effect on partitioning of rare earth elements in the crystallization process of basaltic system at $20 \mathrm{~Kb}$, with some applications. Geochem. J. 11, 21-32.

MCBIRNEY, A. R. and AOKI, K. (1968) Petrology of the island of Tahiti. Geol. Soc. Am. Mem. 116, 523-536.

MORGAN, W. J. (1972) Deep mantle convection plumes and plate motions. Am. Assoc. Petroleum Geologists Bull. 56, 203-213.

NAGASAWA, H. (1970) Rare earth concentrations in zircons and apatites and their host dacites and granites. Earth Planet. Sci. Lett. 9, 359-364.

NAGASAWA, H. (1973) Rare earth distribution in alkali rocks from Oki-Dogo island, Japan. Contr. Mineral. Petrol. 37, 301-308.

NAGASAWA, H. and SCHNETZleR, C. C. (1971) Partitioning of rare earth, alkalic and alkaline earth elements between phenocrysts and acidic igneous magma. Geochim. Cosmochim. Acta 35, 953-968.

NAKAMURA, N. and MASUdA, A. (1976) Chemical composition of the solid phase formed at $20 \mathrm{~kb}$ from a melt with basaltic chemical composition. Geochem. J. 10, 79-83.

NiCHOLLS, I. A. and HARRIS, K. L. (1980) Experimental rare earth element partition ccefficients for garnet, clinopyroxene and amphibole wexisting with andesitic and basaltic liquids. Geochim. Cosmochim. Acta 44, 287-308.

ONUMA, N., HigUCHI, H., WAKITA, H. and NAGASAWA, H. (1968) Trace element partitioning between two pyroxenes and the host lava. Earth Planet. Sci. Lett. 5, 47-51.

RYERSON, F. J. and HESS, P. C. (1978) Implications of liquid-liquid distribution coefficients to mineral-liquid partitioning. Geochim. Cosmochim. Acta 42, 921-932.

SHANNON, R. O. and PREWITT, C. T. (1970) Revised values of effective ionic radii. Acta Crystallogr. Danem. B 26, 1046-1048.

SHAW, D. M. (1970) Trace element fractionation during anatexis. Geochim. Cosmochim. Acta 34, 237-243.

SCHILling, J. G. and WINCHESTER, J. W. (1969) Rare earth contribution to the origin of Hawaiian lavas. Contr. Mineral. Petrol. 23, 27-37.

SHIMIZU, N. and ARCULUS, R. J. (1975) Rare earth element concentrations in a suite of basanitoids and alkali olivine basalts from Grenada, Lesser Antilles. Contr. Mineral. Petrol. 50, 231-240.

SHIMIZU, N. and KUSHIRO, I. (1975) The partitioning of rare earth elements between garnet and liquid at high pressure: Preliminary experiments. Geophys. Res. Lett. 2, 413-416.

SIMmons, E. C. and HEDGE, C. E. (1978) Minorelement and Sr-isotope geochemistry of Tertiary stocks, Colorado mineral belt. Contr. Mineral. Petrol. 67, 379-396.

SCHNETZleR, C. C. and PHILPOTTS, J. A. (1968) Partition coefficients of rare earth elements and barium between igneous matrix and rock-forming mineral phenocrysts. In Origin and distribution of the elements (editor L. H. AHRENS), Pergamon, 929-938.

SCHNETZleR, C. C. and PhilpotTs, J. A. (1970) Partition coefficients of rare earth elements between igneous matrix and rock-forming mineral phenocrysts--II. Geochim. Cosmochim. Acta 34, 331-341.

SUN, S. S. and HANSON, G. N. (1975) Origin of Ross island basanitoids and limitations upon the heterogenity of mantle sources for alkali basalts and nephelinites. Contr. Mineral. Petrol. 52, 77-106.

TANAKA, T. (1974) Rare earth elements in a gabbroic body of the Japanese paleozoic geosyncline. Geochem. J. 8, 74-60.

ZINDLER, A., HART, S. R., FREY, F. A. and JAKOBSSON, S. P. (1979) Nd and $\mathrm{Sr}$ isotope ratios and rare earth element abundances in Reykjanes peninsula basalts: Evidence for mantle heterogenity beneath Iceland. Earth Planet. Sci. Lett. 45, 249-262.

WILSON, J. T. (1963) A possible origin of the Hawaiian Islancs. Canadian J. Phys. 41, 863-870. 